\title{
Reforms Reaffirmed to Improve International Surveillance and Response Mechanism in WHO in the Post-Coronavirus Situation
}

Srijan Pant*

\begin{abstract}
The emergence of COVID - 19 has shown that the inability of WHO to have prompt disease surveillance could be callous to recognize and respond the situation of Public Health Emergency of International Concern (PHEIC). While the paper traces out the timeline of WHO to perform its mandate in combating the spread of infectious diseases, coincidently it also explains the needs to improve the epidemic intelligence on the basis of coordinated international and national surveillance and response mechanism. On the note, the post COVID - 19 situation requires WHO member states to strengthen the institution within the international order of global health governance. The only way to do so will be through effective and prompt global disease surveillance and response system. On the note, the article attempts to shed light on the current and previous reaction of WHO over the infectious diseases including COVID - 19. In the process, this article tries to suggest reforms within the IHR and WHO's applicable effort to develop effective disease surveillance and prompt response system.
\end{abstract}

\section{Introduction: WHO's Role to Control the Spread of Infectious Diseases and the Recurrent Problems Arising due to Lack of a Global Disease Surveillance and Response System}

The World Health Organization (WHO) came into existence after the post-world war period with the objective to improve the existing dire global health situation. ${ }^{1}$ Since then, the WHO has been working to assist on directing and coordinating authority in international health work ${ }^{2}$ with responsibilities including response, control, and elimination of infectious diseases. ${ }^{3}$ For such purposes to direct and coordinate authority,

\footnotetext{
Srijan Pant is a B.A.LL.B. $4^{\text {th }}$ year student at Kathmandu School of Law. He works as a Legal Intern at Infinity Law Firm, Kathmandu. He can be reached at srijan.pant98@gmail.com.

Marcos Cueto, Theodore M. Brown \& Elizabeth Fee, The World Health Organization; A History, Cambridge University Press, United Kingdom, 2019, p. 33.

2 Constitution of the World Health Organization, adopted on $22^{\text {nd }}$ July 1946, International Health Conference, Basic Documents, Forty-fifth edition, Supplement, October 2006, art. 1.

3 This was first proposed by the Chinese and Brazilian delegation in the UN Conference of San Francisco during the state ratification to officially create the WHO. See A. Kamradt Scott, Managing Global Health Security: The WHO and Disease Outbreak Control, Palgrave Macmillan, United Kingdom, 2015, p. 25.
} 
the global disease surveillance and response system has become a quintessential element in the functioning of WHO. However, as this paper will discuss, the WHO has witnessed several problems in the area of global surveillance and response systems. ${ }^{4}$

In 1952, the WHO reached a milestone to respond and coordinate efforts against the outbreaks of infectious diseases with the onset of the World Health Assembly (WHA) adopting the International Sanitary Regulations (ISR)..$^{5}$ Although only six 'notifiable' diseases were covered in its jurisdiction, the document presented a uniform set of prescriptions and recommendations for member states. These affirmative actions under the regulation assisted states to prevent outbreaks of such infectious diseases and epidemics. ${ }^{6}$ More importantly, the formulation of the ISR also led the WHO to initiate critical efforts in major projects such as Malaria Eradication Program (MEP), Smallpox Eradication Program (SEP), TB program and other notified diseases. ${ }^{7}$

Initially enforcing ISR, the WHO took bold efforts and ascertained dominant advisory authority in commanding states to follow stringent temporary recommendations irrespective of its failure concerning the first attempt itself. The Malaria Eradication Program was WHO's first major program under the mandate of ISR. In this project, the WHO maintained plans on aggressive technical support and micromanagement of state policies, for complete eradication of malaria. ${ }^{8}$ In 1950 , the WHO headed by senior executives on malariologists executed the strategy and made an untenable roadmap to fully eradicate malaria with a single design consisting of four phases. ${ }^{9}$

However, this project was launched without the support of the Expert Committee on Malaria which previously had already stated that the organization's bureaucracy limited itself to evaluate, advise, conduct surveillance and promote possible therapeutic agents with the improved distribution. ${ }^{10}$ This meant that the WHO was to prioritize its role to work as a body of international surveillance and response system ${ }^{11}$ and coordinate the national health system, to carry projects execution and campaign for the purposive goal of eradication. ${ }^{12}$ The committee even clarified that the WHO was not mandated

$4 \quad$ International surveillance means the efficiency of WHO network to access, detect and extract raw information about the potential health risks. Response system denotes the ability of WHO to coordinate the efforts of member states to combat the disease including stockpiling of medical necessities and supply to the affected areas as well as provide technical guidance to national authorities through a recommendation to prevent the outbreak of diseases.

Adoption of International Sanitary Resolution, 25 May 1951, WHA Res. 4.75, WHO Regulations No.2.

This regulation included six 'notifiable' diseases including - cholera, plague, typhus, smallpox, yellow fever, and relapsing fever.

Scott (n 3), p. 20.

Ibid.

The four phases were, prepare, attack, consolidate and maintain. See 'Report on the Inter - Regional Conference on Malaria and on the Expert Committee of Malaria', WHO, 1956, Athens, pp. 3-4.

10 Ibid.

11 International surveillance means the efficiency of WHO network to access, detect and extract raw information about the potential health risks. Response system denotes the ability of WHO to coordinate effort of member states to combat the disease including stockpiles medical necessity and supply to the affected areas as well as provide technical guidance to national authorities through recommendation to prevent the outbreak of diseases.

12 Established by the Interim Commission of WHO. 
to provide aggressive technical assistance beyond its capacity of bureaucratic and financial limitations. ${ }^{13}$ The Expert Committee was right as MEP failed to succeed and was eventually suspended in $1973 .{ }^{14}$

The discussion during the first major program of the WHO also showed that the experts were centered and cautious to improve the global surveillance and response system of the WHO, to have effective international coordination and prevent further escalation of suffering from the disease outbreak. Even when the MEP was suspended in 1973, the primary reasons for its failure encircled around the issues of surveillance in malaria epidemic regions including sub - Saharan Africa (i.e., inability of technical access to implement the program) and countries such as China, North Korea and North Vietnam (i.e., non - member states). ${ }^{15}$

However, in the subsequent project itself, the WHO tried to manage these problems. It maintained proper coordination with the national health authorities about the public health situation related to smallpox which worked as a means of coordinating surveillance. Along with this, it also carried out an extensive research to discover new innovative methods to achieve eradication as a means to foster prompt global response. ${ }^{16}$ This led the WHO to achieve great success in the field of the Smallpox Eradication Program (SEP). ${ }^{17}$

However, the great achievement was short-termed and overshadowed by continuous failure in combating HIV AIDS, and Tuberculosis. A report from the US Institute of Medicine (IOM) vehemently criticized the WHO's disease surveillance network, stating that if the organization was to achieve success as in the case of smallpox and polio, the organization must draw its capacity to have a proper global surveillance system. ${ }^{18}$

WHO did not witness any change on the part of its global surveillance network. The influenza surveillance network was the only source it primarily relied upon, to demonstrate its effort to improve the condition of surveillance. ${ }^{19}$ During this period of the 1990s, criticism started to increase against WHO for not responding to such outbreaks with effective measures of surveillance, immediate response and necessary ground information about the affected areas. ${ }^{20} \mathrm{It}$ even started to occupy a position in member states deliberation in WHA where the delegates raised serious concerns over an outbreak of global pandemic and WHO secretariat's inefficiency to act over

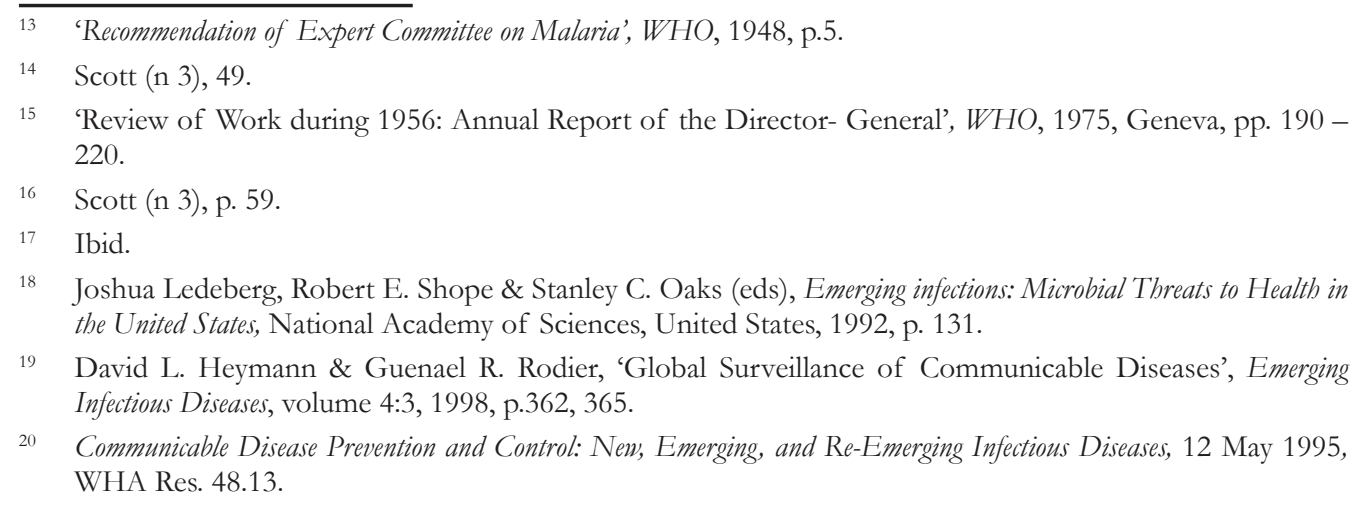


infectious disease as a major body in international health governance. One of the major problems they highlighted during their deliberation was in regards to strengthening global surveillance of infectious disease and emphasized the rapid exchange of outbreak information across national, regional and international levels. ${ }^{21}$

In an attempt to resolve the poor global surveillance and disease verification system, the WHO started to identify and extract outbreak reports from the electronic media which were performed by the Global Public Health Information Network (GPHIN), monitoring almost 600 credible sources. ${ }^{22}$ The then former WHO Director General (DG) Gro Harlem Bruntland, stressed that enhancing the verification system for global disease surveillance would aid in reform of the IHR. ${ }^{23}$ Former DG Bruntland, in the process, carried a policy, 'do first, legislate later'. She established an Emerging and other Communicable Diseases (EMC) Unit and Global Outbreak Alert and Response Network (GOARN). ${ }^{24}$ Among these institutions, the establishment of GOARN is still taken as a pivotal moment to enhance the role of WHO.

This network planned to act promptly in investigation upon the information of the outbreak and intended to give alternatives from the classical approach to rely on governments. This meant that the organization could now have a quick response to control the spread of infectious diseases within and from the affected area. ${ }^{25}$ The establishment of GOARN also maintained a role of the WHO to develop a link of such a response and surveillance system to better the epidemic intelligence which was non-existent before the GOARN came into practice. ${ }^{26}$ The development of such coordination led to the successful end of SARS in just four months. Immediately after the success of containing SARS, the WHA pursued its aims to reform and legislate a new framework of IHR. On 23 May 2005, the WHA reformed the IHR which endorsed WHO's secretariat new approach and a proper guide to manage global health security. ${ }^{27}$

But even as we discuss the improvement in WHO's disease surveillance network and reforms of IHR in 2005, the happenings during Coronavirus shows serious concern in regards to verification and response to situations of a disease outbreaks. The rearrangement of the scope of WHO and member states' responsibility have failed to secure proper coordination for global disease surveillance and response.

21 During the 1990s, the WHO was seen as a failing institution unable to prevent the crisis of Tuberculosis, AIDS and Cholera in Latin America, Plague in Surat, India. This raised attention that ISR and WHO's outbreak policy need urgent reforms. See Scott (n 3), p.106; See also Revision and Updating of the International Health Regulations, 12 May 1995, WHA Res.48.7.

22 Thomas W. Grein et al, 'Rumors of Disease in the Global Village: Outbreak Verification', Emerging Infections Diseases, volume 6:2, 2000, pp. 97 - 99.

23 Revision and Updating of the International Health Regulations (n 21).

24 'Global Outbreak Alert and Response: Report of a WHO Meeting', WHO, 2000, Geneva.

25 Grein et al. (n 22), p. 98.

26 'Report on Global Surveillance of Epidemic-prone Infectious Diseases', WHO, 2000, Geneva, p. 98.

27 This was further clarified by reports released from the director's general in 2007. See 'A Safer Future: Global Public Health Security in the $21^{\text {st }}$ Century', WHO, 2007, Geneva, p. 8 - 11; Revision of the International Health Regulation, 23 May 2005, WHA 58.3. 


\section{Addressing the Authority of WHO under the Reformed IHR 2005 and Questioning its Prompt Response during COVID-19}

The reforms of IHR in 2005 increased the scope of the WHO's responsibility on a wider spectrum. The IHR 2005 intends to be relevant and applicable in the face of continued evolutions of diseases. ${ }^{28}$ This includes a situation of public health emergency of international concern (PHEIC). ${ }^{29}$ Noting the alteration, the reformed IHR secures proper harmony and synchronization between surveillance, response, and reporting systems over a situation of PHEIC or a public health risk encircling WHO member states. Particularly focusing on a possible situation of PHEIC, the IHR secures a calibrated regime to balance the responsibility of member states and subsequently that of the WHO. On part of the WHO, the DG has the ultimate authority to decide on the determination of a PHEIC. ${ }^{30}$ In doing so, the DG entails four essential criteria to declare a situation of PHEIC. ${ }^{31}$ Among the four, the practice of WHO has shown that the information provided by the affected state on the public health crisis remains primary, with other four important criteria. ${ }^{32}$ The information on the possibility of PHEIC shall be provided to WHO within 24 hours of state's assessment over the public health information, by way of the National IHR Focal point. ${ }^{33}$ This duty by member states to notify remains the same even for an unexpected or unusual public health event within its territory. ${ }^{34} \mathrm{WHO}$ can further communicate and ask for verification ${ }^{35}$ on the matter of public health risk. In response, states should provide information collected including human cases, rate of contamination or infection and possible infectious goods due to contamination. ${ }^{36}$

In the case of COVID-19, there seems to be a delayed response to the report on part of China and delayed declaration and surveillance on the part of WHO. According to Lancet Medical Journal, the possibility of the first infectious case could be traced to 22 November 2019. ${ }^{37}$ Sufficient reports have circulated highlighting that the COVID-19

\footnotetext{
28 This did not limit the IHR application to limited notifiable diseases and covered illness or medical conditions irrespective of origin or source that presented or could present significant harm to humans or crisis potentially requiring a coordinated international response. See International Health Regulations, 2005, $3^{\text {rd }}$ eds., WHO: 2016, art. 1.

29 Ibid.

30 Ibid, art. 12.

31 Information of public health situation by affected states, advice from an ad hoc technical expert group known as the Emergency Committee; scientific principles, available scientific evidence, and other related information; an assessment of the risk to human health, of the risk of international spread, and of the risk of interference with international traffic. See Ibid, art. 12.

32 Prof. Sara E. Davies of Griffith University also acknowledged the new reporting expectations from the member states after the revision of IHR in 2005. See S. E. Davies et al., Disease Diplomacy: International norms and global health security, John Hopkins University Press, United States of America, 2015, p. 74.

33 International Health Regulations, 2005 (n 28), art. 6.

34 Ibid, art. 7.

35 Ibid, art. 10.

36 Ibid, art. 9.

37 A.J Kucharski et al., 'Early dynamics of transmission and control of COVID-19: a mathematical modeling study', Lancet Infect. Diseases, volume 20, 2020, pp. 553, 555.
} 
had been seen several weeks before China's first notification about the cluster of cases on 31 December 2019. ${ }^{38}$ The formal legal counsel of the WHO, Gian Luca, explained that China's delay to report on the outbreak and its censored media significantly hampered WHO's ability to coordinate an international response and most importantly understand the threat posed by the virus. ${ }^{39}$ It seems that China has violated its obligation to report such public health information within 24 hours. Irrespective of the role of China in the case, this situation again points out the vulnerability of WHO to depend upon the information provided by affected states. It confronts us with the fact that the WHO is significantly affected by the inability of states to assess and verify the public health situation even within the frameworks of reformed IHR 2005.

Moreover, in the case of COVID-19, there seems to be a delayed response in part of the WHO to declare a PHEIC situation and respond immediately to contain the virus internationally. Dr. Tedros Adhanom Ghebreyesus declared the outbreak of COVID-19 as constituting PHEIC on 30 January $2020 .{ }^{40}$ From late January, the DG started to convey the emergency committee and in the first instance, the committee stressed that declaration of PHEIC did not constitute severity, internationally and was 'too early'. ${ }^{41}$ But as highlighted by a credible medical journal, the surge of the virus had started to show an unprecedented amount of severity which could have required proper clarification. ${ }^{42}$ Even then, WHO remained silent over the inability of the Chinese authority to respond within 24 hours. ${ }^{43}$ The nobility of the reformed IHR 2005 is the authority of WHO to communicate information to the member states about any possible public health risk, taking into account the information or reports from sources other than member states. ${ }^{44}$ WHO can communicate and ask for verification ${ }^{45}$ and states in response, should provide information collected including human cases, rate of contamination or infection and possible infectious goods due to contamination. ${ }^{46}$ WHO did not show any willingness to take any such effort. So, the inability of WHO to communicate with China remains a genuine concern for which the organization should possibly consider to utilize its rights while verifying PHEIC situation in the future.

38 Chaolin Huang et al., 'Clinical features of patients infected with 2019 novel Coronavirus in Wuhan, China' The Lancet, volume 395, 2020, p. 497.

39 Dapo Akande, 'Episode 2: The Podcast! WHO let the Bats Out?', European Journal on International Law, 6 May 2020, available at https://www.ejiltalk.org/ejil-the-podcast-who-let-the-bats-out/, accessed on 3 July 2020 .

40 'Statement on the second meeting of the International Health Regulations (2005) Emergency Committee regarding the outbreak of novel coronavirus (2019-nCoV)', WHO, Geneva, 30 January 2020.

41 The committee discussed that there were very few cases outside of China and the severity was unknown. Therefore, the committee did not see the necessity to declare a situation constituting PHEIC. See 'Statement on the meeting of the International Health Regulations (2005) Emergency Committee regarding the outbreak of novel coronavirus (2019-nCoV)', WHO, Geneva, 23 January 2020.

42 A.J Kucharski (n 37), pp. $555-558$.

43 M. Apuzzo et al., 'How the world missed Covid -19's Silent Spread' The New York. Times, Munich, 27 June 2020, available at https://www.nytimes.com/2020/06/27/world/europe/coronavirus-spreadasymptomatic.html, accessed on 3 July 2020.

44 International Health Regulations, 2005 (n 28), art. 9.

45 Ibid, art. 10.

46 Ibid, art. 9. 
Nonetheless, WHO did declare the outbreak as a PHEIC situation, albeit late. This provided the organization with some imperative authority to contain the outbreak. Initially, after the declaration of PHEIC, the WHO can advise temporary technical guidance, assistance and assesse the effectiveness of control measures and deploy expert teams for on - site assistance. ${ }^{47}$ These measures are temporary and standing recommendations to state parties to control and respond to the particular situation of PHEIC. ${ }^{48}$ Although the recommendation is not binding, WHO as a specialized agency carefully frames recommendations based on expert review and communication with relevant international organizations and state parties. ${ }^{49}$ Therefore, state parties should only avoid the recommendation to take essential measures which are consistent to maintain public health response against the risks of disease. This mandates member states to take actions for managing public health risks beyond the WHO recommendations only with adherence to the following parameters:

i. Based on scientific principles and shreds of evidence, insufficiently provided under the $\mathrm{WHO}$ and other relevant international organizations.

ii. Based on the least invasive restriction to people or to the international traffic in trade and travels among the available alternatives.

iii. Implemented on full respect for the dignity, human rights and fundamental freedom of persons. ${ }^{50}$

Failing to do so would show the inability of member states to control, protect and provide a public health response against a PHEIC. ${ }^{11}$ Boycotting the recommendation and refraining from its duty to report and respond to the public health risks would be a breach of its obligations ultimately under articles 21 and 22 of the WHO Constitution. ${ }^{52}$

For this matter, states and WHO should have continuous interaction over the best possible outcome to prevent the consequences of outbreaks of diseases. After the press conference of the second meeting of the DG and the Emergency Committee, Dr. Tedros declared the COVID-19 outbreak as PHEIC and emphasized WHO's role to focus on countries with weaker public health systems. ${ }^{53}$ Theoretically, from the provisions of IHR, it is understood that after the declaration, WHO makes temporary recommendations and the states, excluding exceptional cases, would follow the direction to have a better public health situation. However, the WHO could not perform this duty mentioned under the obligation of IHR while responding to COVID-19. In a global context, 24 countries had imposed export restrictions on medical equipment

\footnotetext{
$47 \quad$ Ibid., art. 13 .

48 Ibid., part III.

49 This involves consulting with key partners within the UN system such as World Trade Organization (WTO), International Civil Aviation Organization (ICAO) and Food and Agriculture Organization (FAO) as well as international aid agencies including World Bank, Asian Development Bank (ADB). See 'International Health Regulations (2005): Areas of work for implementation', WHO, 2007, Lyon, p. 18.

50 International Health Regulations, 2005 (n 28), art. 43(3).

$51 \quad$ Ibid, arts. $41 \& 42$.

52 WHO Constitution (n 2), arts. 21 \& 22.

53 Statement on the second meeting of the International Health Regulations (n 40).
} 
including surgical masks, respirators, gowns and goggles till 11 March $2020 .{ }^{54}$ However, WHO had advised against travel and trade restrictions until March. Even then, 51 countries had announced border closure by 18 February 2020. Interesting to note is the fact that only a proportion of countries met their legal obligation to notify and report about such restrictive measures. ${ }^{55}$

This shows that the calibrated regime envisioned within the IHR framework, coordinating the $\mathrm{WHO}$ and member states obligation requires effective reforms. The lack of a prompt mechanism to detect and respond to the public health emergency has yet again attached serious speculation in WHO's effort to govern the global health situation.

\section{Realizing the Recurring Challenges of WHO during COVID-19 and Reaffirming the Reforms in IHR}

The lack of an effective interaction between the WHO and the member states to implement IHR has again reaffirmed the reforms in the field to coordinate international and national surveillance and response systems. There seem to be reasonable grounds to suspect that WHO delayed its declaration of COVID-19 as a situation of PHEIC. During the declaration on 30 January, the cases of infection had already spiked to 18 countries. ${ }^{56}$ However, this is not the first time that WHO has delayed its response to declare an endangered situation as PHEIC.

There are six instances where the DG declared a situation of PHEIC, in cases of Zika, Influenza H1N1, Ebola, Polio and recently in the case of COVID-19. ${ }^{57}$ The declaration in PHEICs has been delayed even in circumstances of scientific certainty and serious speculation on public health risk from the disease, which can be even observed in this case. The Wuhan Municipal Health Commission had reported a cluster of cases of novel Coronavirus on 31 December 2019 and reports entailed the possible transmission started from November. ${ }^{58}$

Previously in 2015, Brazil was quick to observe a rise in Microcephaly cases but the Brazilian Ministry of Health established emergency operation centers in affected

54 Countries included influential health suppliers US, India and Germany. See Soumaya Keynes \& Chad P. Bown, 'Episode 125: Coronavirus and Trade Restrictions', Peterson Institute for International Economics,2020, available at https://www.tradetalkspodcast.com/podcast/125-coronavirus-and-trade-restrictions/, accessed on 3 July 2020.

55 Caroline Foster, 'Justified Border Closures do not violate the International Health Regulations 2005', EJIL Talks ,11 June 2020, available atejiltalk.org/justified-border-closures-do-not-violate-theinternational-health-regulations-2005/, accessed on 3 July 2020.

56 Statement on the second meeting of the International Health Regulations (n 40).

57 Lawrence O. Gostin, Roojin Habibi, \& Benjamin Mason Meier, 'Has Global Health Law Risen to Meet the Coronavirus Challenge? Revisiting the IHR to prepare for Future threats', Journal of Law, Medicine \& Ethics, volume 48:2,2020, p.4.

58 M.E. Turner, 'Coronavirus Syposium: The Declaration of a PHEIC in International Law', OpinioJuris Post, 31 March 2020, available at http://opiniojuris.org/2020/03/31/COVID-19-symposium-the-declarationof-a-public-health-emergency-of-international-concern-in-international-law/, accessed on 3 July 2020. 
areas only after a month. The slow mobilization of Brazil to declare the public health situation by the Zika outbreak as a national emergency was prolonged by WHO because the declaration of PHEIC was announced only after two months of Brazil's delayed response to the outbreak.

During the 2014 Ebola outbreak, WHO was quite aware of the severity of the situation. To respond, it responsibly created an emergency response team, deployed GOAN, Medicins Sans Gronteieries in the field for investigation and surveillance. ${ }^{59}$ However, the Ebola outbreak confirmed on 22 March 2014 was only determined as PHEIC on 8 August 2014, when the disease had already exhibited risks in rural and local areas of Guinea, Liberia, and Sierra Leone. ${ }^{60}$

Ironically, this is not, however, true for response of influenza H1N1 which was less severe to public health as compared to Zika or Ebola or Coronavirus. Prof. S.J. Hoffman provides a hypothesis that the WHO was probably concerned about the rate of contamination while determining the extent of public health risk. ${ }^{61}$

Problems of member states including China's inability to report the public health situation within 24 hours is not the first challenge faced by WHO in regards to coordination with a member state. The Chinese authority omitted its de facto responsibility to provide prompt information about the context of the SARS virus in 2002 as well. On 27 November 2002, a potential influenza outbreak was observed in Southern China by network agencies of WHO, Global Influenza Surveillance Network (GISN). China dismissed the WHO request for further information and no further action took place. Immediately, in early February 2003, a series of atypical pneumonia occurred in the borders across Southern China. This was the same influenza seen on 27 November, commonly known as SARS. ${ }^{62}$

The situation of the state's inability for a timely response was even visible during the Ebola outbreak. The Ebola outbreak in West Africa had resulted in the spread of infection among several people in the remote border regions between Guinea, Liberia and Sierra Leone prior to 26 December 2013. However, this was undetected for 3 months and initially, the spread of the disease infected more than 21,700 people and killed 8,600 people. ${ }^{63}$

This situation highlights two aspects: first, the importance of the declaration of

59 Steven J Hoffman \& Sarah L Silverberg, 'Delays in Global Disease Outbreak Responses: Lessons from H1N1, Ebola and Zika', American Journal on Public Health, volume 10:3, 2017, pp. 329, 330.

60 U.S Department of Health and Human Services, '2014 - 2016 Ebola Outbreak in West Africa', Centers for Disease Control and Prevention, 8 March 2019, available at https://www.cdc.gov/vhf/ebola/history/20142016-outbreak/index.html, accessed on 3 July 2020.

61 Hoffman (n 59).

62 Timothy J. Brookes, Omar A. Khan, Bebind the Mask: How the World Survival SARs. The First Epidemic of the Twenty first Century, Johns Hopkins University Press, United States of America, 2007, p.180.

${ }_{63}$ 'Ground Zero in Guinea: The Outbreak Smoulders - Undetected - For more than Three Months: A Retrospective on the First Cases of the Outbreak', WHO, 2014, available at https://www.who.int/csr/ disease/ebola/ebola-6-months/guinea/en/, accessed on 3 July 2020.. 
outbreak as PHEIC and second, dependence on information and assessment of states to declare the situation as PHEIC.

In the first part, the declaration of an outbreak as PHEIC gives certain authority to the WHO including, the power to advise on temporary recommendations. ${ }^{64}$ In this context, the WHO should focus on other criteria as much as state's assessment of possible risks according to article 12 of IHR including available scientific evidence and assessment of the risk of human health, the international spread of disease. ${ }^{65}$ As highlighted previously, in the case of uncertainty and speculation, the WHO should effectively use its ability to ask verification with the member states on a public health situation under article 9 of IHR which is based on information other than that of state actors. ${ }^{66}$ In doing so, there can be a decrease in delay to declare a health crisis as a PHEIC situation due to reluctance of states. Secondly, in regards to the dependence on information and the state's assessment to declare the situation as PHEIC. The WHO should focus on building its intelligence network and adopt an alternative and more efficient verification system of disease outbreak beyond the absolute discretion of the state's effort to provide information. Rather, it is necessary to envision a synchronized effort to coordinate the intelligence network and national authorities to impart and disseminate information on possible public health risks at a better pace from the current state of the verification system. In the process, the WHO should also coordinate with the national response and surveillance mechanism to strengthen the global disease surveillance and mechanism in the status quo. The reform in IHR has brought a provision for $\mathrm{WHO}$ to rely upon non - state actors to collect information and conduct the ground reality to understand the public health situation. ${ }^{67}$ For the part, global disease surveillance must be based on a network of expert channels to obtain raw epidemiological data, integrating with the WHO regional offices and local partners including the GOARN and the United States Centers for Disease Control and Prevention (CDC).$^{68}$ Furthermore, among the minimum core capacities, IHR must make it mandatory for states to develop a prompt national surveillance network in association with National IHR points prior to the lapse of a year. This will eventually assist in proper coordination between the WHO and the member states for immediate international response in the situation constituting a PHEIC.

During the response to COVID-19, we witnessed the lack of coordination and enforcement of temporary recommendations of WHO by member states as discussed in the previous section. ${ }^{69}$ To overcome this situation, the WHO should prioritize strengthening its approach to self-evaluate the response of states to interrupt the

\footnotetext{
64 International Health Regulations, 2005 (n 28), art. 15(1).

65 Ibid., art. 12(4).

66 Ibid., art. 9.

67 Ibid., art. 9.

68 'International Health Regulations 2005: Areas of work for implementation', WHO, June 2007, Lyon, p. 3.

69 Gian Luca Burci, 'The International Association Calls for Greater Cooperation and Investment to address Pandemic Outbreaks', The Graduate Institute Geneva, 9 April 2020, available at https://graduateinstitute. $\mathrm{ch} /$ communications/events/international-law-association-calls-greater-cooperation-and-investment, accessed on 3 July 2020.
} 
inappropriate measures. As provided in the Reparations Advisory Opinion of the International Court of Justice (ICJ), 'under international law, that organization must be deemed to have those powers which, though not expressly provided in the Charter, are conferred upon it by necessary implication as being essential to the performance of its duties. ${ }^{70}$ The actions performed by the states were strongly restrictive towards international trade and travel and lacked scientific principles and evidence sufficient to overcome temporary recommendations of WHO, including lockdown and PCR testing including in the US and Brazil. ${ }^{71}$ These actions connote explicit violation of articles 41 and 42 of IHR which require states to take health measures pursuant to the regulations and for the purpose to achieve greater level of health protection than the WHO recommendations. ${ }^{72}$ As of WHO, it is essential for IHR to attach the organization with the responsibility in bearing a self - evaluation approach to ascertain states' response and necessary international response over the PHEIC. Among the four key areas of work, under IHR, WHO must strengthen the global alert and response system. ${ }^{73}$ In the cases of previous outbreak like Ebola, WHO had obtained responses based on the establishment to Interim Assessment panel, ${ }^{74}$ but WHO requires a permanent body to consistently look upon the state's action. For this purpose, WHO has developed voluntary mechanisms like Joint External Evaluation (JEE) accompanying core areas to prevent, detect, and respond to IHR related issues. ${ }^{75}$ The JEE plays an essential role to prevent and reduce the outbreaks and events in omission on part of responsibility by states which promotes development of a tendency within WHO to initiate coordinated health response over the possibility of crisis. The adoption of JEE is part of a customary practice prescribed by the WHO, 'do first, legislate later'. ${ }^{76}$ In this process, IHR must also prioritize the role to govern corporations and other non-governmental actors which is not in existence till this point. ${ }^{77}$ The post Coronavirus stage could be best suited to establish such coordinates under the obligation of IHR.

There is however already a link established between the obligation of member states to perform the regulation adopted by World Health Assembly under article 22 of WHO constitution. ${ }^{78}$ This provides the assembly to direct recommendations to countries

Ro Reparation for Injuries Suffered in the service of the United Nations, Advisory Opinion,1949, ICJ Rep. 174, 182, p. 5.

71 'Brazil: Bolsonaro Sabotages Anti-COVID-19 Efforts: President Flouts Health Authorities' Advice, Undermines Access to Information', Human Rights Watch, Sao Paulo, 10 April 2020, available at https:// www.hrw.org/news/2020/04/10/brazil-bolsonaro-sabotages-anti-COVID-19-efforts, accessed on 3 July 2020.

72 IHR, arts. $42 \& 43$.

73 WHO, International Health Regulations 2005: Areas of work. for implementation (n 68), 5.

74 Ibid, 16.

75 'Technical Framework in support to IHR 2005 Monitoring and Evaluation: Joint External Evaluation Tool ', WHO, 2005, France, p.8.

76 S. Davies, 'Internet Surveillance and disease outbreaks 'in Simon Rushton, Jeremy R. Youde (eds), The Politics of Surveillance and Response to Disease Outbreak, Routledge Publication, United Kingdom, ${ }^{\text {st }}$ eds., 2015, pp. $226-238$.

${ }_{77}$ Roojin Habibi et al., 'Do not violate the International Health Regulations during the CORONAVIRUS Outbreak', The Lancet, volume 395:10225, 2020, pp.664- 665.

78 Regulations adopted under Article 21 shall come into force for all Members after due notice has been given of their adoption by the Health Assembly except for such Members as may notify the Director-General of 
to oblige states in bringing their actions in conformity with the WHO constitution, subsequently the IHR. ${ }^{79}$ In this process, the WHO can 'name and shame' violating state parties and officially demand justifications for additional health measures. ${ }^{80}$ This creates a certain international pressure for states to comply with health protection measures. However, pursuing a strong adjudicatory power will be counter-effective to the organization's response to maintain global health security if WHO does not have a stable economic source to sustain its global programs. WHO faces a serious problem in utilizing and convincing state and non-state actors to fund its programs and activities. Only $20 \%$ of the WHO funds are mandatory for the US which means $80 \%$ of the funding depends upon voluntary contribution of state and non - state actors. ${ }^{81}$ In the current situation, WHO has an annual budget of $\$ 4.422$ billion which can be compared with Nepal's latest fiscal year budget which is $\$ 90.69$ billion. ${ }^{82}$ The crisis is evident as for the first time, WHO appealed to the general public for financial support to launch Coronavirus Solidarity Response Fund. ${ }^{83}$ This comes with the deterrent threat from major donor state (i.e. US) to cut down its share of WHO funding in response to the complicit act of the international organization to favor China ${ }^{84}$ In this situation, utilizing the adjudicatory strength of WHO can deepen the political biases instead of curing the health-related problems. For the matter member states should engage to invest fixed contributory budgets to counter any sort of undue political influence.

\section{Conclusion}

The WHO does not have the role to act as 'first responder' but works as 'directing and coordinating authority' in international health. ${ }^{85}$ This clarifies some of the limitations it considers necessary to execute its mandate under its limited financial and bureaucratic resources. However, there is no doubt that the post international order in health governance, should include WHO with a more efficient role of surveillance and

rejection or reservations within the period stated in the notice. See WHO Constitution, art. 22.

79 WHO Constitution (n 2), art. 23.

80 Lawrence O Gostin, Mary C Debartolo\& Eric A Friedman, 'The International Health Regulations 10 Years On: The Governing Framework for Global Health Security', The Lancet, Volume 386, 2015, p. 2225.

81 Suerie Moon, 'Debate: It's time for us all to fund the World Health Organization', The Graduate Institute Geneva, 28 April 2020, available at https://graduateinstitute.ch/communications/news/debate-its-time-usall-fund-world-health-organization, accessed on 3 July 2020.

82 E. Joshi, 'Government increases budget for the health sector to Rs. 90. 69 million' The Kathmandu Post,Kathmandu, 28 May 2020,available at https://kathmandupost.com/money/2020/05/28/ government-increases-budget-for-the-health-sector-to-rs $90-69$ billion\#: :text $=$ The $\% 20$ government $\% 20$ has $\% 20$ raised $\% 20$ the,of $\% 20$ the $\% 20$ Covid $\% 2$ D $19 \% 20$ pandemic, accessed on 3 July 2020.

83 Suerie Moon, (n 81).

84 Teo Armus, 'Trump threatens to permanently cut WHO funding, leave body if changes aren't made within 30 days', The Washington Post, Washington DC, 19 May 2020, available at https://www.washingtonpost. $\mathrm{com} /$ nation/2020/05/19/who-funding-trump/, accessed on 3 July 2020 ..

85 Dr. Margaret Chan explained the authority of WHO, describing agency's Ebola Operations. See Sheri Fink, 'WHO leader describes the Agency's Ebola Operations', The New York Times, New York, 4 September 2014, available at https://www.nytimes.com/2014/09/04/world/africa/who-leader-describes-the-agencys-ebola-operations. btml, accessed on 3 July 2020. 
respond to a possible situation of PHEIC. As mentioned in this article, the WHO's effort to respond to the situation of COVID-19 has shown necessary improvements upon the global surveillance system for prompt verification and response to a possible situation of PHEIC. During the 1990s, however, the WHO improved the surveillance mechanism but the effort remained fragmented as member states attained priority, rather than the secretariat. ${ }^{86}$ In a broader sense, surveillance and response require proper coordination between national and international health system which can be denoted by a 'synchronized system' to accompany WHO networks and national health authorities through the National IHR focal point. It is necessary for WHO to improve its epidemic intelligence to suppress the criticism it faced during the response to COVID-19. In early July, 239 scientists from 39 countries wrote an open letter claiming that the recommendations of the WHO in regard to airborne transmissions were outdated. ${ }^{87}$ On the note that one event should not be generalized to devalue efforts from the organization, but the prompt response from the scientists should be given prior recognition. The revision on this part within IHR can not only increase the scope of epidemic intelligence but it can also increase the WHO's scope to assess the responsibility of states under compliance with IHR. This will also ensure that the purpose of calibrated effort between WHO and national health authority is achieved as envisioned within the IHR and in any case of disobedience, relevant information will be stacked to 'name and shame' member states omitting their responsibility. Furthermore, it is necessary for the WHO to maintain the surveillance and response mechanism effectively on human settlements near the wildlife habitats as the majority of infectious diseases recently have occurred from these areas through the transmission of pathogens from animal to human bodies. ${ }^{88}$

Also discussed in this article, the only possible way to avoid political intervention and strengthen the WHO's adjudicatory mechanism is to improve its approach to selfevaluation through global surveillance and a system of mandatory contribution for its budget. In illustrating the necessity to improve the surveillance system within the WHO, it is equally important for organization to obtain financial and technical supports ${ }^{89}$ from member states and civil society organizations including Bill and Melinda Gates Foundation and the Rockefeller Foundation to build such core capacities. ${ }^{90}$ This will assist WHO to fulfill its responsibility from two aspects. First, WHO will not fully depend upon the affected states to obtain the information about the public health risk and on the note delay its international response through declaration of an outbreak as PHEIC; second, the information under its network can be utilized effectively for

\footnotetext{
86 The reforms in 2005 did not change WHO's efforts to give priority to the non - states information and assessment information in that regard as evident from the case of Coronavirus.

87 Lidia Morawska, Donald K Milton, 'It is time to Address Airborne Transmission of Coronavirus', Clinical Infectious Diseases p. 2311, volume 71:9, 2020.

88 The disease occurring from these transmissions are Zoonoses. See Katherine F Smith et al., 'Global rise in human infectious disease outbreaks', The Royal Society Publishing, volume 11:101, 2014, pp. 1, 5.

89 Gian Luca Burci, (n 69).

$90 \quad$ Ali Tejpar et al., 'Canada's Violation of International Law during the 2014 - 16 Ebola Outbreak', The Canadian Yearbook of International Law, volume 54, 2016, pp.366, 382.
} 
research and assessment about the possible threat of the disease. The prompt reaction will not only save lives but will also provide a proper data source to acknowledge the future threat and risks of a possible outbreak of infectious disease. Concluding, the observation points out to the fact that the post COVID-19, it is necessary to create determinant role of global actors to address the reoccurring issues of global disease surveillance and response system and for the matter, strengthen the ability under WHO to deescalate preventable damages. 